\title{
SPACE DEBRIS: THE ASPECTS OF THE PROBLEM
}

\author{
Institute of Technical Mechanics \\ of the National Academy of Sciences of Ukraine and the State Space Agency of Ukraine \\ 15 Leshko-Popel St., Dnipro 49005, Ukraine; e-mail:sazinana@ukr.net
}

The aim of this work is a system analysis of the engineering features of the deorbiting of space debris fragments. New results reflect a possibility to change the concept of near-Earth space debris mitigation from space debris elimination to space debris utilization. The paper presents a brief analysis of different aspects of the problem of space debris mitigation in near-Earth space. Different methods and means to prevent the space debris formation and to reduce space debris population are considered. Scientific problems involving the development of methods and means for near-Earth space debris mitigation are formulated.

Keywords space debris, spacecraft protection, near-Earth space cleaning, tether systems, space debris deorbiting, active removal, cluster, utilization orbit.

1. Technogenic Clogging of Near-Earth Space (in Russian). A. P. Alpatov (Ed.). Dnepropetrovsk: Porogi, 2012. 378 pp.

2. Space Debris. In two books. Book 1. Space Debris Observation Methods and Models (in Russian). G. G. Raikunov (Ed.). Moscow: FIZMATLIT, 2014. 245 pp.

3. Space Debris. In two books. Book 2. Space Debris Prevention (in Russian). G. G. Raikunov (Ed.). Moscow: FIZMATLIT, 2014. 188 pp.

4. Technical report on space debris. United Nations. New York, 1999. 50 pp.

5. Alpatov A. P., Zakrzhevskiii A. E. Passive Deployment of a Pair of Connected Bodies in Orbit (in Russian). Prikladnaya Mekhanika. 1999. V. 35. No. 10. Pp. 87-92.

6. Alpatov A. P., Gusynin V. P. , Belonozhko P. P. , Khoroshilov S. V. , Fokov A. A. Shape control of large reflecting structures in space. 62nd International Astronautical Congress, Cape Town, SA. Copyright (C2011 by the International Astronautical Federation. All rights reserved. IAC-11.C2.3.6

7. Bombardelli C., Herrera J., Iturri A., Pelaez J. Space debris removal with bare electrodynamic tethers. Proceedings of the 20th AAS: AIAA Spaceflight Mechanics Meeting, San Diego, CA, 2010.

8. Bombardelli C., Pelaez.J. Ion beam shepherd for contactless space debris removal. Journal of Guidance, Control and Dynamics. 2011. V. 34. No. 3. Pp. 916-920.

9. Estes R. D., Lorenzini E. C., Sanmartin J., Pelaez J., Martinez-Sanchez M., Johnson C. L., Vas I. E. Bare Tethers for Electrodynamic Spacecraft Propulsion. Journal of Spacecraft and Rockets. 2000. V. 37. Pp. $205-211$.

10. Bombardelli C., Alpatov A. P., Pirozhenko A. V., Baranov E. Yu., Osinovyi G. G., Zakrzhevskii A. E. Ion beam shepherd project. Ideas and problems (in Russian). Kosmichna Nauka i Tehnologia, 2014. V. 20. No. 2. Pp. 55-60.

11. Alpatov A. P., Fokov A. A., Khoroshylov S. V. Determination of the optimum position of an ion beam shepherd with respect to a space debris object (in Russian). Ukrainian Conference on Space Research. Abstracts (Odessa, Ukraine, August 25-28, 2015). Odessa, 2015. P. 126.

12. Alpatov ., Cichocki F., Fokov A., Khoroshylov S., Merino M. Algorithm for Determination of Force Transmitted by Plume of Ion Thruster to Orbital Object Using Photo Camera. Proceeding of the 66th International Astronautical Congress (Jerusalem, Israel, 2015. IAC-15-A6.5.5-27732). Jerusalem, 2015.

13. Alpatov A., Cichocki F., Fokov A., Khoroshylov S., Merino M. Determination of the force transmitted by an ion thruster plasma plume to an orbital object. Acta Astronautica. 2016. No. 119. Pp. 241-251.

14. Alpatov A. P., Paliy A. S., Skorik A. D. Aerodynamic systems for removing space objects. Tekhnicheskaya Mekhanika, 2015. No. 4. Pp. 126-138.

15. Polyakhova E. N. Space Flight under Solar Sail: Problems and Prospects. Moscow: Nauka, 1986. 304 pp.

16. Alpatov A. P., Belonozhko P. P., Tarasov S. V., Fokov A. A., Khramov D. A. Space robotics prospects (in Russian). Information Technologies in Metallurgy and Mechanical Engineering: conference proceedings (Dnepropetrovsk, March 25-27, 2014). Dnepropetrovsk, 2014. Pp. 5-6.

17. Sanjurjo Rivo M. Self Balanced Bare Electrodynamic Tethers. Space Debris Mitigation and other Applications : tesis doctoral N 1839 / Manuel Sanjurjo Rivo. Madrid, 2009. 215 pp.

18. Alpatov A. P., BeletskyV. V., Dranovskii V. I., Khoroshilov V. S., Pirozhenko A. V., Troger H., Zakrzhevskii A. E. Dynamics of Tethered Space Systems. Boca Raton, London, New York: CRC Press, 2010. 223 pp.

19. Levin E. M. Dynamic analysis of space tether missions. San Diego: American Astronautical Society, 2007. $453 \mathrm{p}$.

20. Fujii H. A. \& others Sounding rocket experiment of bare electrodynamic tether system. Journal of Acta Astronautica, 2009, V. 64, No. 2-3. Pp. 313-324.

21. Alpatov A. P., Gorbulin V. P. Space platforms for orbital industrial complexes: problems and prospects (in Russian). Visnyk NAN Ukrainy. 2013. No. 12. Pp. 26-38. 
22. Alpatov A. P., Goldstein $Y$ u. M. Ballistic analysis of the orbit distribution of spacecraft for different functional missions (in Russian). Technical Mechanics. 2017. No. 2. Pp. 33-41. 